\title{
SISTEM INFORMASI ADMINISTRASI KEUANGAN SEKOLAH BERBASIS WEB (STUDI KASUS: SMK AL-KAHFI)
}

\author{
Eri Sasmita Susanto ${ }^{1}$, Fahri Hamdani², Yuyun Tari ${ }^{3}$ \\ ${ }^{1), 2)}$ Dosen Informatika, Universitas Teknologi Sumbawa \\ 3) Mahasiswa Informatika, Universitas Teknologi Sumbawa \\ $\underline{\text { eri.sasmita.susanto@uts.ac.id }}^{1}$, fahri.hamdani@uts.ac.id ${ }^{2}, \underline{\text { yuyuntari022@gmail.com }}^{3}$
}

\begin{abstract}
Abstraksi
SMK Al-Kahfi adalah sekolah tempat dimana penulis melakukan penelitian. Pada saat ini, sistem pengelolaan administrasi keuangan sekolah tersebut masih dilakukan secara manual sehingga menyebabkan banyak pembukuan, penulisan data yang berulang-ulang, dan keterlambatan pembuatan laporan. Solusi dari permasalahan yang sedang terjadi di SMK Al-Kahfi adalah penerapan teknologi informasi yaitu membangun sebuah sistem informasi yang dapat membantu pengelolaan sistem administrasi keuangan sekolah dengan lebih efisien. Maka dari itu tujuan dari penelitian ini adalah pembuatan Sistem Informasi Administrasi Keuangan Sekolah Berbasis Web pada SMK Al-Kahfi. Sistem ini dikembangkan menggunakan bahasa pemrogramman PHP Hypertext Preprocessor (PHP) dan MySql sebagai database. Dengan adanya sistem informasi yang dibangun diharapkan dapat membantu petugas keuangan dalam proses pengolahan data administrasi keuangan sekolah sehingga menghasilkan sistem informasi administrasi keuangan sekolah yang tertata baik.
\end{abstract}

Kata Kunci : Sistem, Informasi, Administrasi Keuangan, PHP, Waterfall.

\begin{abstract}
Al-Kahfi Vocational School is a place where writers conduct research. At this time, the school's financial administration management system is still done manually, causing a lot of bookkeeping, repeated writing of data, and delays in making reports. The solution to the problem that is happening at Al-Kahf Vocational School is the application of information technology, namely building an information system that can help manage the school's financial administration system more efficiently. So from that the purpose of this study is the creation of a Web-Based School Financial Administration Information System at Al-Kahf Vocational School. This system was developed using the PHP programming language Hypertext Preprocessor (PHP) and MySql as a database. The existence of an information system built is expected to be able to help financial officers in the processing of school financial administration data so as to produce a well-organized school financial administration information system.
\end{abstract}

Keyword: System, Information, Financial Administration, PHP, Waterfall.

\section{PENDAHULUAN}

\section{A. Latar Belakang}

Perkembangan teknologi saat ini telah berkembang sangat cepat dan membawa perubahan yang sangat besar, karena dengan teknologi tersebut informasi dapat diperoleh dengan cepat, akurat dan tidak terbatas oleh waktu dan tempat. Hal ini membuat banyak organisasi dan lembaga pendidikan membutuhkan suatu teknologi informasi untuk kegiatan pengolahan data sekolah dan menyajikan informasi secara cepat dan akurat. Sekolah Menengah Kejuruan Al-Kahfi merupakan lembaga pendidikan swasta yang berbasis pondok di bawah naungan yayasan Dea Mas yang berdiri pada tanggal 2 Agustus tahun 2014 yang beralamat di Jl. Olat Maras, Desa Pernek, Kecamatan Moyo Hulu, Kabupaten Sumbawa. Seiring bertambahnya waktu SMK Al-Kahfi mengalami perkembangan yang signifikan.
Perkembangan ini menuntut adanya suatu proses yang semula konvensional menjadi terkomputerisasi untuk mempercepat kinerja dan efisiensi dalam administrasi sekolah termasuk juga masalah administrasi keuangan.

Permasalahan yang sering muncul pada bagian administrasi keuangan sekolah yaitu berupa mencatat pemasukan keuangan, pengeluaran hingga pembuatan laporan. Sistem administrasi keuangan sekolah yang sedang berjalan saat ini masih dilakukan secara manual yaitu mencatat data dalam buku, seperti pencatatan iuran pembayaran siswa, dana sumbangan dari para donatur dan Bantuan Operasi Sekolah (BOS), sehingga sulit dalam pengerjaan dan pengumpulan data-data keuangan serta masih sering terjadinya kesalahan dalam pengolahan data administrasi keuangan pada sekolah tersebut. 
Sistem ini masih kurang efektif, karena proses pengelolaan data keuangan dalam proses administrasi yang ada sampai ke pembuatan laporan keuangan yang memakan waktu lebih lama, karena harus terlebih dahulu mencari data tersebut dari buku atau arsip - arsip.

Berdasarkan uraian permasalahan di atas, maka diperlukan sebuah aplikasi berbasis web sebagai fasilitas untuk membantu pengelolaan administrasi keuangan sekolah supaya lebih efektif dan efisien mulai dari proses administrasi hingga pembuatan laporan keuangan sekolah. Oleh karena itu, penulis mencoba membangun "Sistem Informasi Administrasi Keuangan Sekolah Berbasis Web" (Studi Kasus : SMK Al-Kahfi).

Penulis berharap dengan adanya sistem informasi yang dibangun dapat membantu petugas keuangan dalam proses pengolahan data administrasi keuangan sekolah sehingga menghasilkan sistem informasi administrasi keuangan sekolah yang tertata baik.

\section{B. Rumusan Masalah}

Berdasarkan uraian latar belakang diatas, maka dapat dirumuskan masalah dalam penelitian ini adalah "Bagaimana Merancang dan Membangun Sistem Informasi Administrasi Keuangan Sekolah Berbasis Web pada SMK Al-Kahfi?”.

\section{Batasan Masalah}

Agar penelitian ini lebih terarah dan tidak menyimpang dari masalah yang ada, maka ditetapkan beberapa batasan masalah sebagai berikut:

1. Sistem informasi administrasi keuangan ini hanya dapat di akses oleh Bendahara (admin), Kepala Sekolah dan Kepala Yayasan

2. Penulis hanya membangun sistem informasi administrasi keuangan pembayaran siswa, Pemasukan Dana Sumbangan Pendidikan (DSP) dan pengeluaran pada SMK Al-Kahfi..

3. Laporan yang dihasilkan meliputi laporan data siswa, laporan Pemasukan Dana Sumbangan Pendidikan (DSP), laporan pembayaran siswa dan laporan pengeluaran

4. Sistem ini dibuat menggunakan bahasa pemrograman PHP

5. Database yang digunakan adalah database MySql.

\section{Tujuan Penelitian}

Sesuai dengan konsep yang ada, untuk menyelesaikan penelitian maka tujuan yang ingin dicapai dari penelitian ini adalah Merancang dan Membangun Sistem Informasi Administrasi Keuangan Sekolah Berbasis Web pada SMK AlKahfi.

\section{LANDASAN TEORI}

\section{A. Tinjauan Pustaka}

Selama ini telah banyak penelitian yang mengkaji tentang aplikasi-aplikasi terkait sistem informasi administrasi keuangan salah satunya penelitian yang berjudul Sistem Informasi Keuangan Berbasis Desktop dengan Java Standard Edition \& Mysql di Sekolah Tinggi Teknologi Nurul Jadid Paiton Probolinggo [1].

Mereka melakukan penelitian tersebut dengan tujuan untuk mempermudah pekerjaan karyawan yang ada di bagian Keuangan dalam proses pengelolahan data keuangan pada Bagian Keuangan di STT Nurul Jadid yang dilakukan secara manual. Dengan diterapkan sebuah sistem yang terkomputerisasi berbasis desktop untuk proses pengelolahan data keuangan pada Bagian Keuangan di STT Nurul Jadid, sistem ini nantinya akan menyimpan, mengolah dan menampilkan semua informasi yang berkaitan dengan keuangan di lembaga tersebut.

Sistem Administrasi Keuangan Sekolah dengan Menggunakan Java (Studi Kasus: Program Studi Teknik Informatika, Fakultas Komunikasi dan Informatika Universitas Muhammadiyah Surakarta), dimana pada penelitian tersebut dapat membantu pengelolaan sistem administrasi sekolah yang dilatar belakangi karena kurang efisiennya sistem pengelolaan data siswa, pengelolaan data SPP siswa, dan pengelolaan pembayaran ujian yang terdapat pada SMA Muhammadiyah 4 Andong [2].

Dari penelitian yang telah dilakukan seperti diatas penulis juga melakukan penelitian tentang Sistem Informasi Administrasi Keuangan Sekolah Berbasis Web (Studi Kasus: SMK Al-Kahfi) yang tujuannya adalah untuk menghasilkan sebuah Sistem administrasi keuangan sekolah yang dapat membantu petugas keuangan dalam mengatasi banyak pembukuan yang didalamnya terdapat banyak jenis pembukuan sebagai acuan pengadministrasiaannya, mempercepat kinerja pengguna sistem untuk dapat mengelola data keuangan dengan menginput, menyimpan dan mencetak data sesuai kebutuhan untuk dijadikan laporan.

\section{B. Dasar Teori \\ 1. Sistem}

Sistem dapat didefinisikan dengan pendekatan prosedur dan dengan pendekatan komponen. Dengan pendekatan prosedur, sistem dapat didefinisikan sebagai kumpulan dari prosedur-prosedur yang mempunyai tujuan tertentu. dengan pendekatan komponen, sistem dapat didefinisikan sebagai kumpulan dari komponen yang saling berhubungan satu dengan yang lainnya membentuk satu kesatuan untuk mencapai tujuan tertentu [3]. 


\section{Informasi}

Informasi adalah data yang telah diolah menjadi suatu bentuk yang penting bagi si penerima dan mempunyai nilai nyata atau yang dapat dirasakan dalam keputusan-keputusan yang sekarang atau keputusan-keputusan yang akan dating [4].

\section{Administrasi Keuangan}

Administrasi keuangan sekolah adalah langkah pengolahan keuangan sekolah yang dimulai dari penerimaan hingga bagaimana keuangan yang digunakan dipertanggungjawabkan secara obyektif dan sistematis. Langkah tersebut sangat penting untuk diperhatikan, sebab pembiayaan merupakan sarana vital yang akan mempengaruhi keberlangsungan proses pendidikan di suatu sekolah [5].

\section{PHP Hypertext Preprocessor (PHP)}

PHP adalah singkatan dari "PHP Hypertext Preprocessor", yang merupakan sebuah bahasa scripting yang terpasang pada HyperText Markup Language (HTML) . PHP merupakan sebuah bahasa pemograman yang berjalan dalam sebuah webserver. Sebagian besar sintaks mirip dengan bahasa $\mathrm{C}++$, Java, ditambah beberapa fungsi PHP yang spesifik. PHP dapat melakukan apa saja yang bisa di lakukan oleh pemograman CGI lain, yaitu mengolah data dengan tipe apapun, menciptakan halaman web yang dinamis, serta menerima dan menciptakan data cookies. PHP juga dapat berjalan pada semua jenis sistem informasi operasi antara lain Linux dan Microsoft, serta dapat berjalan pada beberapa webserver antara lain Apache, IIS, Personal Web Server, Caudium [6].

\section{Metode Pengembangan Perangkat Lunak}

Metode waterfall mengusulkan sebuah pendekatan perkembangan perangkat lunak yang sistematik dan skuensial. Disebut dengan waterfall karena tahap demi tahap yang dilalui harus menunggu selesainya tahap sebelumnya dan berjalan berurutan [7].

Berikut ini tahapan-tahapan dalam pengembangan perangkat lunak menggunakan metode waterfall :

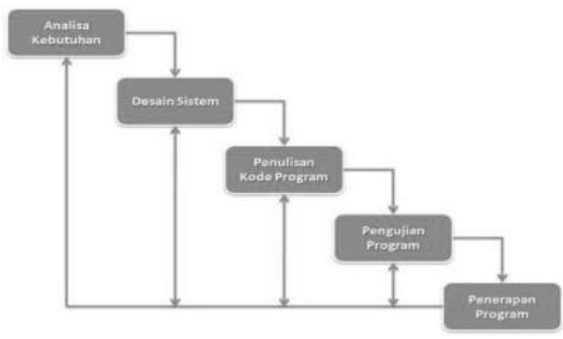

Gambar 1. Metode Waterfall a. Analisa Kebutuhan

Analisa kebutuhan merupakan tahap awal yang dilakukan oleh peneliti dalam mengembangkan sistem yang sedang berjalan pada SMK Al-Kahfi. Selain menganalisa sistem yang berjalan peneliti juga menganalisa kebutuhan perangkat lunak dan perangkat keras dan penggunaan data.

b. Desain Sistem

Tahap ini bertujuan membuat rancangan dari aplikasi yang akan dibuat. Perancangan dilakukan dengan pemodelan tersturuktur menggunakan Data Flow Diagram (DFD) .

c. Penulisan Kode Program

Pada tahap ini akan dipastikan bahwa setiap fitur yang ada pada perangkat lunak berfungsi dengan baik. Peneliti menggunakan bahasa pemrograman PHP dan database yang digunakan adalah database $\mathrm{MySql}$.

d. Pengujian Program

Pada tahapan ini dilaksanakan dengan uji coba sistem oleh pengguna, apakah sistem yang telah dibuat terdapat error atau kesalahan dan memastikan apakah sistem sudah layak atau perlu disempurnakan lagi. Pada pengujian aplikasi digunakan pengujian black box.

e. Penerapan Program

Pada tahap ini penulis melakukan pengoperasian aplikasi yang telah selesai dibuat pada SMK Al-Kahfi untuk mengganti sistem yang sebelumnya menggunakan cara konvensional.

\section{Flowchart}

Flowchart merupakan sebuah diagram dengan simbol-simbol grafis yang menyatakan aliran algoritma atau proses yang menampilkan langkahlangkah yang di simbolkan dalam bentuk kotak, beserta urutan dengan menghubungkan masingmasing langkah tersebut menggunakan tanda panah. Diagram ini bisa memberi solusi selangkah demi langkah untuk penyelesaian masalah yang ada di dalam proses atau algoritma tersebut.

Flowchart adalah bagan-bagan yang mempunyai arus yang mengambarkan langkahlangkah penyelesaian suatu masalah.flowchart merupakan cara penyajian dari suatu algoritma [8].

\section{Data Flow Diagram (DFD)}

Data Flow Diagram (DFD) merupakan alat pemodelan data yang menggambarkan sistem sebagai suatu jaringan dari fungsi-fungsi atau proses-proses dari sistem yang saling berhubungan satu sama lain dengan aliran data yang digambarkan dengan anak panah.

Data Flow Diagram (DFD) merupakan model dari sistem untuk menggambarkan pembagian sisstem ke modul yang lebih kecil [8]. 


\section{Pengujian Software}

Blackbox menentukan prilaku sistem atau bagian sistem. Sistem (atau bagian) menggapi rangsangan stimulan tertentu (peristiwa) dengan menerapkan seperangkat aturan transisi yang memetakan rangsangan stimulan ke respons [9].

\section{METODOLOGI PENELITIAN}

\section{A. Metode Penelitian}

Adapun metode penelitian ini menggunakan 2 metode yaitu metode penelitian kualitatif yang bersifat deskriptif dan metode pengembangan perangkat lunak. Metode kualitatif adalah penelitian yang dilakukan untuk mengetahui nilai variabel mandiri, baik satu variabel atau lebih (independen) tanpa membuat perbandingan, atau penghubungan dengan variabel yang lain [10]. Sedangkan metode pengembangan perangkat lunak yang digunakan dalam skripsi ini adalah metode waterfall (air terjun) dimana mengusulkan sebuah pendekatan perkembangan perangkat lunak yang sistematik dan skuensial. Disebut dengan waterfall karena tahap demi tahap yang dilalui harus menunggu selesainya tahap sebelumnya dan berjalan berurutan [7].

\section{Metode Pengumpulan Data}

Adapun prosedur pelaksanaan dalam pengumpulan data adalah sebagai berikut :

a. Wawancara

Pada tahap ini peneliti melakukan pengumpulan data melalui tanya jawab dan diskusi dengan petugas keuangan SMK AlKahfi untuk mendapatkan informasi terkait dengan administrasi keuangan di SMK AlKahfi.

b. Observasi

Pada tahap observasi peneliti mengumpulkan data dengan cara mengamati secara langsung proses yang terjadi di objek penelitian, sehingga data yang diperoleh sesuai dengan kejadian di lapangan.

c. Dokumentasi

Dokumentasi merupakan salah satu tahapan peneliti dalam pengumpulan data, dimana peneliti menyelidiki benda-benda tertulis seperti buku-buku, dokumen, jurnal, dan referensi yang berhubungan sesuai dengan objek yang diteliti.

\section{1). Teknis Analisis Data}

Untuk menganalisis data yaitu data yang telah terkumpul dikelompokkan untuk memudahkan penggolongan dalam pengolahan data dalam Sistem Informasi Administrasi Keuangan Sekolah Berbasis Web (Studi Kasus : SMK AlKahfi).

\section{2). Keabsahan Temuan (Triangulasi)}

Keabsahan temuan dilakukan dengan cara kembali kepada narasumber dalam hal ini Bendahara SMK Al-Kahfi. Adapun kegunaan keabsahan temuan untuk memastikan data tersebut valid, sehingga bisa dilanjutkan ke tahap perancangan.

\section{Metode Pengembangan Perangkat Lunak}

Berikut ini tahapan-tahapan dalam pengembangan perangkat lunak menggunakan metode waterfall :

a. Analisa Kebutuhan

Analisa kebutuhan merupakan tahap awal yang dilakukan oleh peneliti dalam mengembangkan sistem yang sedang berjalan pada SMK Al-Kahfi. Selain menganalisa sistem yang berjalan peneliti juga menganalisa kebutuhan perangkat lunak dan perangkat keras dan penggunaan data.

b. Desain Sistem

Tahap ini bertujuan membuat rancangan dari aplikasi yang akan dibuat. Perancangan dilakukan dengan pemodelan tersturuktur menggunakan Data Flow Diagram (DFD) .

c. Penulisan Kode Program

Pada tahap ini akan dipastikan bahwa setiap fitur yang ada pada perangkat lunak berfungsi dengan baik. Peneliti menggunakan bahasa pemrograman PHP dan database yang digunakan adalah database MySql.

d. Pengujian Program

Pada tahapan ini dilaksanakan dengan uji coba sistem oleh pengguna, apakah sistem yang telah dibuat terdapat error atau kesalahan dan memastikan apakah sistem sudah layak atau perlu disempurnakan lagi. Pada pengujian aplikasi digunakan pengujian black box.

e. Penerapan Program

Pada tahap ini penulis melakukan pengoperasian aplikasi yang telah selesai dibuat pada SMK Al-Kahfi untuk mengganti sistem yang sebelumnya menggunakan cara konvensional.

\section{B. Alat dan Bahan Penelitian}

Adapun alat dan bahan yang dibutuhkan dalam penelitian yaitu, kebutuhan perangkat dan kebutuhan data. Kebutuhan perangkat yang digunakan berupa perangkat keras(hardware), perangkat lunak (software) dan kebutuhan pengguna(user) dengan hak aksesnya sesuai dengan kebutuhan penelitian yang dilakukan. Sedangkan untuk kebutuhan data yang digunakan berupa datadata yang berkaitan dengan penelitian yang dilakukan.

\section{Alur Penelitian}

Adapun alur penelitian dapat dilihat pada gambar 3.1 berikut : 


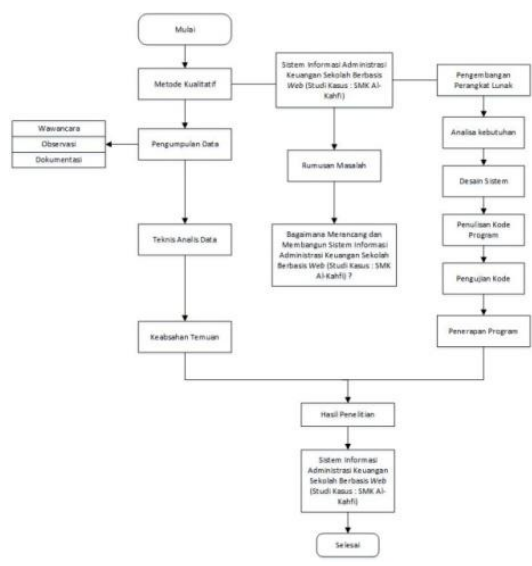

Gambar 2. Alur Penelitian

\section{Hasil dan Pembahasan}

\section{A. Alur Kerja Sistem Berjalan}

Berdasarkan hasil wawancara yang dilakukan penulis pada SMK Al-Kahfi diketahui sistem yang berjalan pada saat ini memiliki alur seperti yang terlihat pada gambar 4.1 adalah sebagai berikut :

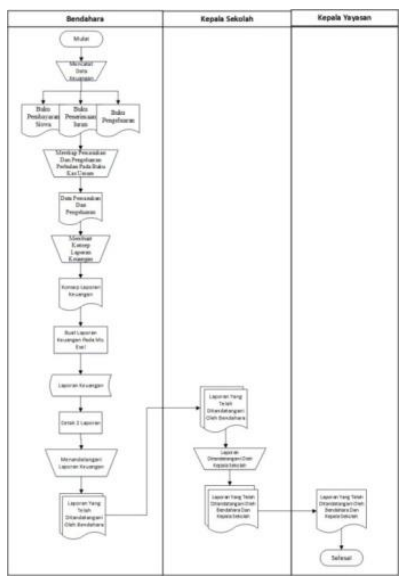

Gambar 3. Sistem Yang Sedang Berjalan

Berdasarkan gambar alur kerja sistem yang sedang berjalan, maka dapat didefinisikan kelemahan-kelemahan dari sistem yang sedang berjalan tersebut, yaitu sebagai berikut:

1. Pencatatan data keuangan masih menggunakan banyak jenis pembukuan.

2. Bendahara melakukan pengecekan dan mencari data kembali untuk melihat pembayaran sebelumnya.

3. Bendahara melakukan pemindahan data dari pembukuan untuk pembuatan laporan keuangan.

\section{B. Kerja Sistem Yang Diusulkan}

Berdasarkan masalah-masalah yang telah dijelaskan sebelumnya, penulis bermaksud mengusulkan pembuatan sistem informasi yang memudahkan administrasi keuangan agar petugas keungan tidak lagi menggunakan cara yang manual.
Secara garis besar alur kerja sistem yang akan diusulkan penulis pada SMK Al-Kahfi dapat digambarkan sebagai berikut :

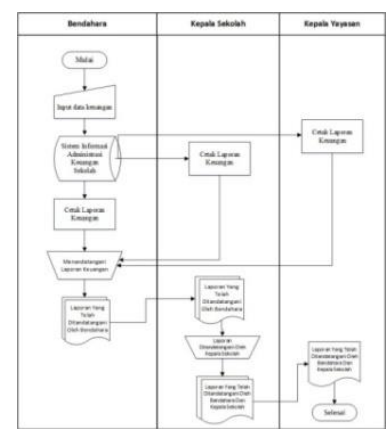

Gambar 4. Sistem Yang Diusulkan

Alur kerja yang akan diusulkan pada SMK Al-Kahfi secara garis besar adalah Bendahara melakukan penginputan data keuangan ke dalam sebuah sistem, dimana data yang telah di input tersimpan dalam sebuah database dan dapat dikirimkan langsung ke Kepala Sekolah dan Kepala Yayasan untuk dijadikan sebuah laporan keuangan.

\section{Diagram Konteks}

Berikut adalah diagram konteks dari Sistem Informasi Administrasi Keuangan Sekolah Berbasis Web pada SMK Al-Kahfi yang dibuat untuk mengetahui hubungan langsung antar user dengan sistem, yaitu sebagai berikut:

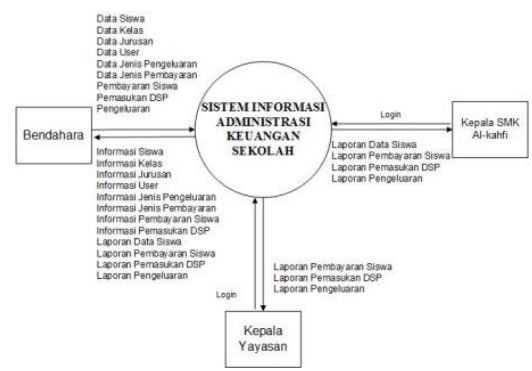

Gambar 5. Diagram Konteks

\section{Data Flow Diagram (DFD)}

Berikut adalah DFD level 1 dari Sistem Informasi Administrasi Keuangan Sekolah Berbasis Web pada SMK Al-Kahfi yang menggambarkan semua alur kerja sistem yang akan dibangun yaitu sebagai berikut :

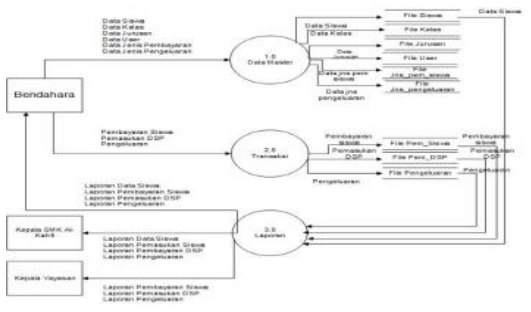

Gambar 6. Data Flow Diagram Level 1 
Proses-proses yang terlibat adalah :

1. Data Master

Data master adalah data dasar berupa data siswa, kelas, jurusan, jenis pembayaran, jenis pengeluaran dan data user yang digunakan sebagai acuan untuk melakukan proses pengelolaan data pada sistem.

2. Transaksi

Transaksi dimana proses tersebut berupa hasil pendataan keuangan berupa pemasukan DSP, pembayaran siswa dan pengeluaran.

3. Laporan

Laporan ditujukan kepada Kepala SMK Al-Kahfi dan Kepala Yayasan berupa laporan data siswa, pemasukan DSP, pembayaran siswa dan pengeluaran namun juga dapat dicetak oleh Bendahara.

1. Data Flow Diagram (DFD) Level 2 Proses 1.0

Berikut adalah DFD level 2 proses 1.0 dari

Sistem Informasi Administrasi Keuangan Sekolah Berbasis Web pada SMK Al-Kahfi, yaitu sebagai berikut:

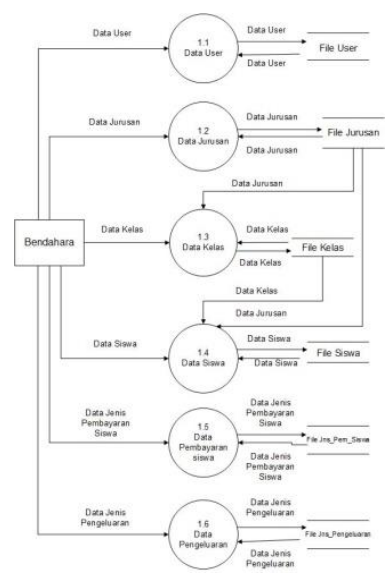

Gambar 7. Data Flow Diagram Level 2 Proses 1.0

2. Data Flow Diagram (DFD) Level 2 Proses 2.0

Berikut adalah DFD level 2 proses 2.0 dari Sistem Informasi Administrasi Keuangan Sekolah Berbasis Web pada SMK Al-Kahfi, yaitu sebagai berikut:

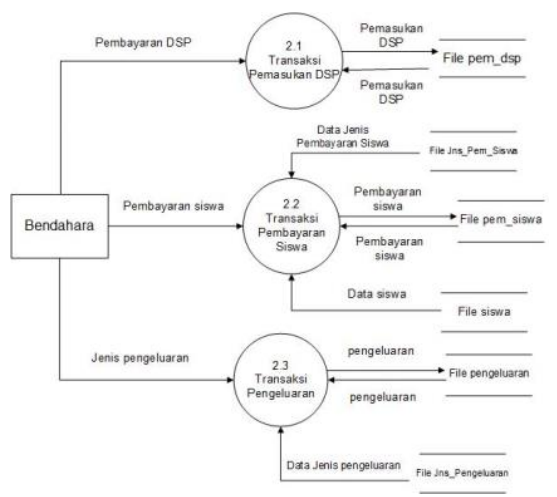

Gambar 8. Data Flow Diagram Level 2 Proses 2.0
3. Data Flow Diagram (DFD) Level 2 Proses 3.0

Berikut adalah DFD level 2 proses 3.0 dari Sistem Informasi Administrasi Keuangan Sekolah Berbasis Web pada SMK Al-Kahfi, yaitu sebagai berikut:

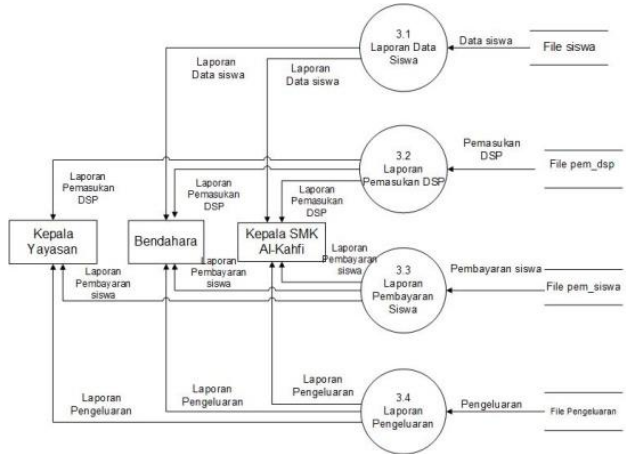

Gambar 9. Data Flow Diagram Level 2 Proses 3.0

\section{E. Entity Relationship Diagram (ERD)}

Berikut adalah Entity Relationship Diagram (ERD) dari Sistem Informasi Administrasi Keuangan Sekolah Berbasis Web pada SMK AlKahfi, yaitu sebagai berikut:

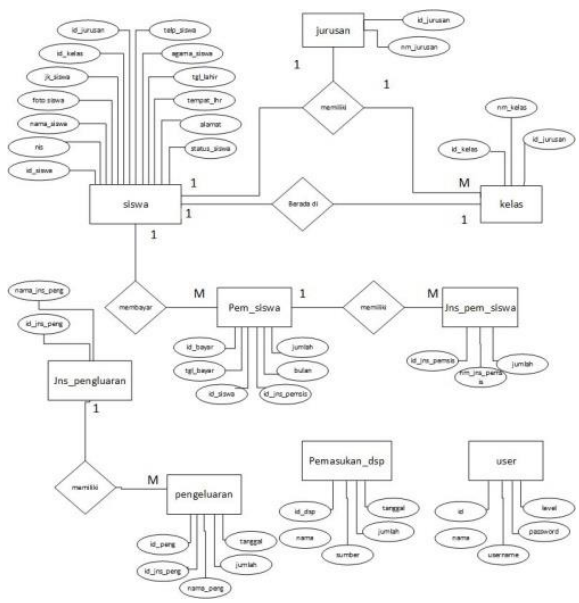

Gambar 10. Entity Relationship Diagram

\section{F. Perancangan User Interface}

Berikut ini penjabaran tentang perancangan user interface dari Sistem Informasi Administrasi Keuangan Sekolah

Berbasis Web pada SMK Al-Kahfi, yaitu sebagai berikut.

\section{Rancangan Interface Form Login}

Adapun rancangan interface form login adalah sebagai berikut: 


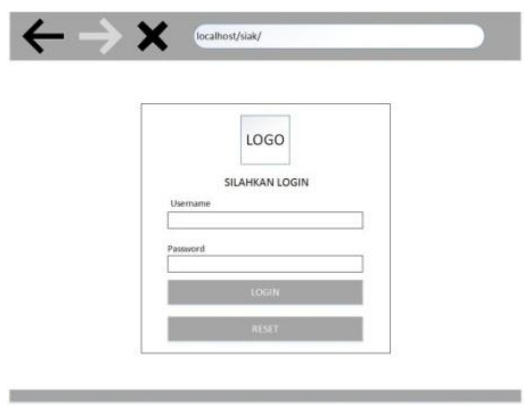

Gambar 11. Rancangan Interface Form Login

2. Rancangan Interface Halaman Dashboard Pada Admin

Adapun rancangan interface halaman dashboard pada admin adalah sebagai berikut:

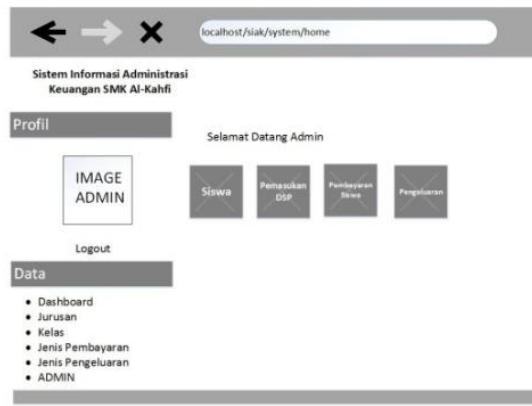

Gambar 12. Rancangan Interface Halaman Dashboard Pada Admin

3. Rancangan Interface Halaman Dashboard Kepala SMK Al-Kahfi

Adapun rancangan interface halaman Dashboard Kepala SMK Al-Kahfi adalah sebagai berikut:

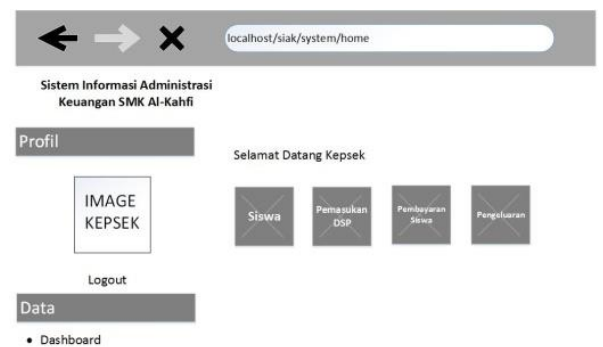

Gambar 13. Rancangan Interface Halaman Dashboard Kepala SMK Al-Kahfi

4. Rancangan Interface Halaman Dashboard Kepala Yayasan

Adapun rancangan interface halaman Dashboard Kepala yayasan adalah sebagai berikut:

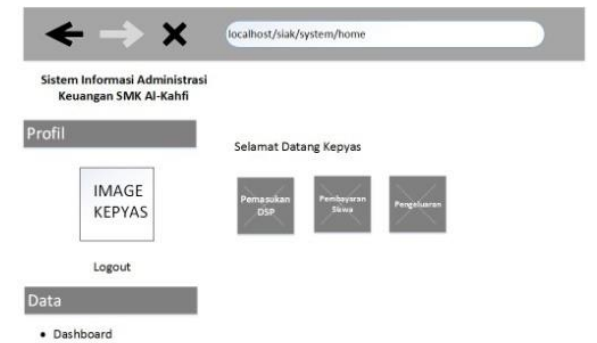

Gambar 14. Rancangan Interface Halaman Dashboard Kepala Yayasan

\section{G. Pengujian Aplikasi}

Berikut adah tabel pengujian blackbox berdasarkan Sistem Informasi Administrasi Keuangan Sekolah Berbasis Web pada SMK AlKahfi, yaitu sebagai berikut:

Tabel 1. Pengujian Aplikasi

\begin{tabular}{|c|c|c|}
\hline $\begin{array}{c}\text { Skenario } \\
\text { Pengujian }\end{array}$ & $\begin{array}{c}\text { Hasil } \\
\text { Pengujian }\end{array}$ & Kesimpulan \\
\hline $\begin{array}{l}\text { Mengisi } \\
\text { Username dan } \\
\text { Password } \\
\text { dengan data } \\
\text { yang salah, } \\
\text { lalu langsung } \\
\text { klik button } \\
\text { Silahkan } \\
\text { Login. }\end{array}$ & $=$ & Sukses \\
\hline $\begin{array}{l}\text { Mengisi } \\
\text { Username dan } \\
\text { Password } \\
\text { Admin dengan } \\
\text { benar, lalu } \\
\text { langsung klik } \\
\text { button } \\
\text { Silahkan } \\
\text { Login. }\end{array}$ & 8 & Sukses \\
\hline $\begin{array}{l}\text { Mengisi } \\
\text { Username dan } \\
\text { Password } \\
\text { Kepala SMK } \\
\text { Al-Kahfi } \\
\text { dengan benar, } \\
\text { lalu langsung } \\
\text { klik button } \\
\text { Silahkan } \\
\text { Login. }\end{array}$ & 8 & Sukses \\
\hline
\end{tabular}




\begin{tabular}{|l|l|l|}
\hline Mengisi & \\
Username dan & \\
Password & \\
Kepala SMK & & \\
Yayasan & & \\
dengan benar, & & \\
lalu langsung & & \\
klik button & & \\
Silahkan & & \\
Login. & & \\
\hline
\end{tabular}

Berdasarkan hasil pengujian dengan kasus uji sample di atas dapat ditarik kesimpulan bahwa Sistem Informasi Administrasi Keuangan Sekolah Berbasis Web pada SMK Al-Kahfi secara fungsional mengeluarkan hasil sesuai dengan yang diharapkan.

\section{Kesimpulan Dan Saran \\ A. Kesimpulan}

Dari hasil analisa dan perancangan sistem yang telah dilakukan sebelumnya, maka penulis dapat mengambil kesimpulan bahwa Sistem Informasi Administrasi Keuangan Sekolah Berbasis Web (Studi Kasus : SMK Al-Kahfi) berhasil dirancang dan dibangun menggunakan bahasa pemrograman PHP 5.4 dengan Database MySQL serta telah diuji menggunakan metode pengujian Blackbox. Dengan terselesainya Sistem Informasi Administrasi Keuangan Sekolah Berbasis Web ini, penulis berharap sistem ini mudah digunakan oleh Bendahara SMK Al-Kahfi dalam menginput data pemasukan, pengeluaran dan mencetak laporan keuangan sekolah. Sehingga Merancang dan Membangun Sistem Informasi Administrasi Keuangan Sekolah Berbasis Web (Studi Kasus : SMK Al-Kahfi) yang dapat memudahkan Bendahara SMK Al-Kahfi dalam pengolahan data administrasi keuangan pada SMK Al-Kahfi, serta menghasilkan sistem informasi administrasi keuangan sekolah yang tertata baik.

\section{B. Saran}

Terbangunnya Sistem Informasi Administrasi Keuangan Sekolah Berbasis Web (Studi Kasus : SMK Al-Kahfi) ini masih jauh dari kesempurnaan, dengan demikian dalam hal ini sebagai evaluasi bagi pembaca nantinya agar Sistem Informasi Administrasi Keuangan Sekolah Berbasis Web ini dapat dikembangkan. Maka dari itu diharapkan kedepannya sistem yang dibangun dapat mencakup keseluruhan sistem administrasi keuangan sekolah dan data siswa dari sistem ini terpisah dengan data siswa dari sistem akademik yang sedang berjalan, diharapkan sistem ini mempunyai integrasi dengan sistem akademik

\section{Daftar Pustaka}

[1] Huda, Syaiful. (2013). Sistem Informasi Keuangan Berbasis Desktop Dengan Java Standard Edition \& Mysql Di Sekolah Tinggi Teknologi Nurul Jadid Paiton Probolinggo”. Skripsi. Probolinggo : Teknik Informatika Sekolah Tinggi Teknologi Nurul Jadid Paiton Probolinggo.

[2] Purnomo, Indrawan Ari, Sudjalwo \& Yusuf Sulistyo Nugroho. "Sistem Administrasi Keuangan Sekolah dengan Menggunakan Java". Skripsi. Surakarta: Informatika Universitas Muhammadiyah Surakarta

[3] Jogiyanto. 2008. Sistem Teknologi Informasi. Yogyakarta: Andi.

[4] Hutahean, Joperson. 2014. Konsep Sistem Informasi. Yogyakarta : Deepublish.

[5] Gumilar, Sarah Kyla, Wardani Muhammad \& Suryatiningsih. (2017) . "Aplikasi Berbasis Web Pengelolaan Keuangan Sekolah (Studi Kasus: Ma Persis Tarogong Garut)". e-Proceeding of Applied Science, Vol. 3, No. 2, hlm. 665 (Maret 2018)

[6] Peranginagin, Kasiman. 2006. Aplikasi Web dengan PHP dan MySql. Yogyakarta : Andi.

[7] Sasmito, W. Ginanjar. 2017. "Penerapan Metode Waterfall Pada Desain Sistem Informasi Geografis Industri Kabupaten Tegal" Jurnal Informatika: Jurnal Pengembangan IT (JPIT) Vol. 2, No. 1. ISSN: 2477-5126 Hlm 8. (Maret 2019).

[8] Ladjamudin, Al-Bahra Bin. 2013. Analisis dan Desain Sistem Informasi. Yogyakarta: Graha Ilmu.

[9] Pressman, Roger, S. 2012. Rekayasa Perangkat Lunak. Yogyakarta : Andi Diterjemahkan Oleh : Adi Nugroho, ST., MM., Si.; George John Leopold Nikijuluw, S.Pd.; Theresia Herlina Rochadiani, S.Kom., MT.; Ike Kurniawati Wijaya, ST, MT.

[10] Maturidi, Ade Djohar. 2014. Metode Penelitian Teknik Informatika. Yogyakarta: deepublish 